\title{
Respiratory Outcomes in Patients Following COVID-19-Related Hospitalization: A Meta-Analysis
}

\author{
Tao Guo ${ }^{1}$, Fangfang Jiang ${ }^{2}$, Yufei Liu ${ }^{3}$, Yunpeng Zhao ${ }^{4}$, Yiran $L^{5}{ }^{5}$ and Yihua Wang ${ }^{1 *}$ \\ ${ }^{1}$ Biological Sciences, Faculty of Environmental and Life Sciences, University of Southampton, Southampton, United Kingdom, \\ ${ }^{2}$ Department of Mathematical Sciences, Faculty of Social Sciences, University of Southampton, Southampton, United Kingdom, \\ ${ }^{3}$ School of Food Science and Technology, Jiangnan University, Wuxi, China, ${ }^{4}$ School of Medicine and Integrated Medicine, \\ Nanjing University of Chinese Medicine, Nanjing, China, ${ }^{5}$ School of Artificial Intelligence and Information Technology, Nanjing \\ University of Chinese Medicine, Nanjing, China
}

OPEN ACCESS

Edited by:

Rana Jahanban-Esfahlan,

Tabriz University of Medical

Sciences, Iran

Reviewed by:

Doaa El Amrousy,

Faculty of Medicine, Tanta University,

Egypt

Effat Alizadeh,

Tabriz University of Medical

Sciences, Iran

Giovanni Barisione,

IRCCS Ospedale Policlinico San

Martino, Italy

${ }^{*}$ Correspondence:

Yihua Wang

yihua.wang@soton.ac.uk

Specialty section: This article was submitted to

Molecular Diagnostics and

Therapeutics,

a section of the journal

Frontiers in Molecular Biosciences

Received: 30 July 2021 Accepted: 07 September 2021

Published: 06 October 2021

Citation:

Guo T, Jiang F, Liu Y, Zhao Y, Li Y and Wang $Y$ (2021) Respiratory Outcomes in Patients Following COVID-19Related Hospitalization: A MetaAnalysis.

Front. Mol. Biosci. 8:750558. doi: $10.3389 /$ fmolb.2021.750558
Background: To determine the respiratory outcomes in patients following COVID-19related hospitalization.

Methods: Systematic review and meta-analysis of the literature.

Results: Forced vital capacity (FVC, \% of predicted): 0-3 months post discharge: 96.1, 95\% Cl [82.1-110.0]; 3-6 months post discharge: 99.9, 95\% Cl [84.8, 115.0]; >6 months post discharge: $97.4,95 \% \mathrm{Cl}$ [76.8-118.0]. Diffusing capacity of the lungs for carbon monoxide (DLCO, \% of predicted): 0-3 months post discharge: 83.9, 95\% Cl [68.9-98.9]; 3-6 months post discharge: 91.2, 95\% Cl [74.8-107.7]; >6 months post discharge: 97.3, 95\% Cl [76.7-117.9]. Percentage of patients with FVC less than $80 \%$ of predicted: $0-3$ months post discharge: $10 \%$, 95\% Cl [6-14\%]; 3-6 months post discharge: 10\%, 95\% Cl [2-18\%]; >6 months post discharge: $13 \%, 95 \% \mathrm{Cl}$ [8-18\%]. Percentage of patients with DLCO less than $80 \%$ of predicted: 0-3 months post discharge: 48\%, 95\% Cl [41-56\%]; 3-6 months post discharge: 33\%, 95\% Cl [23-44\%]; >6 months post discharge: 43\%, 95\% Cl [22-65\%].

Conclusion: The meta-analysis confirms a high prevalence of persistent lung diffusion impairment in patients following COVID-19-related hospitalization. Routine respiratory follow-up is thus strongly recommended.

Keywords: COVID-19, follow-up, pulmonary function test, FVC, DLCO, synthesis review, meta-analysis

\section{INTRODUCTION}

To date, over 200 million people worldwide have recovered from COVID-19 (https://www.worldometers. info/coronavirus/) (Worldometers (2020). Worl, 2020), but concern remains that some organs, including the lungs, might suffer long-term impairment following recovery from acute infections. Individual studies have shown that residual abnormalities of pulmonary function were observed in a subgroup of recovered COVID-19 patients, with the most common finding being a reduction in gas transfer as measured by diffusing capacity of the lungs for carbon monoxide (DLCO) (Hull et al., 2020; Dhawan et al., 2021;

Abbreviations: BMI, body mass index; COVID-19, Corona virus disease 2019; DLCO, diffusing capacity for carbon monoxide; FVC, forced vital capacity; NR, not reported; PFTs, pulmonary function tests. 
Thomas et al., 2021). In this study, with meta-analysis, we aimed to determine the short (0-3 months), medium (3-6 months) and long (>6 months) respiratory outcomes in patients following COVID-19related hospitalisation. The findings will instruct appropriate interventions for subsequent increased healthcare utilisation postCOVID-19.

\section{METHOD}

\section{Criteria for Inclusion}

We included randomised controlled trials (RCTs) and observational studies (cross-sectional, longitudinal, case-control and cohort) of patients with a confirmed diagnosis of COVID-19. The studies included aimed to determine the respiratory outcomes, in particular

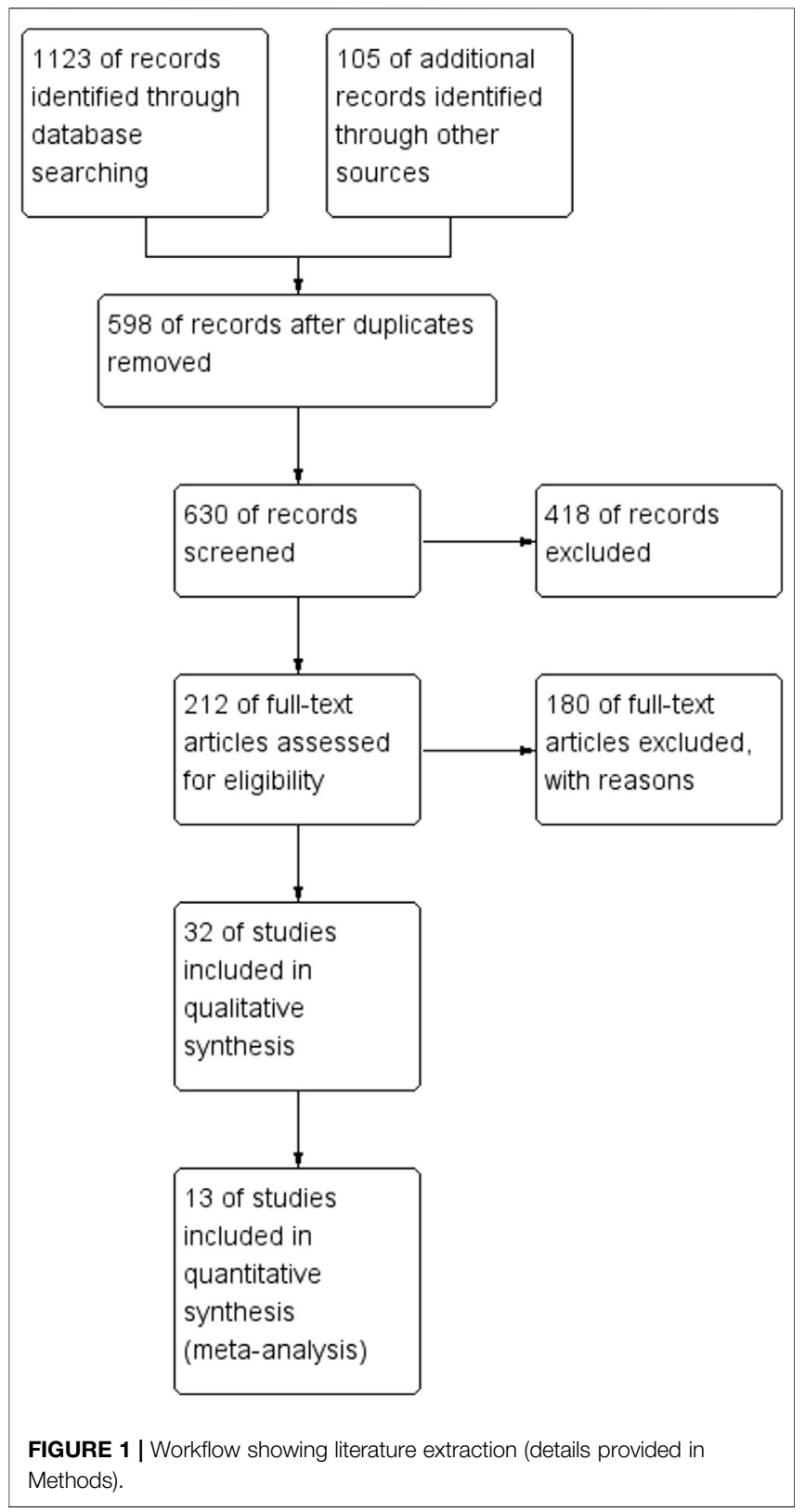

forced vital capacity (FVC) and diffusing capacity of the lungs for carbon monoxide (DLCO), in patients following COVID-19-related hospitalisation. The selected studies had to follow the ATS / ERS clinical guidelines. The included literatures should be published before May 15, 2021.

\section{Criteria for Exclusion}

Study's subjects who were not infected with COVID-19. Studies didn't report the time of hospital discharge or the time was calculated from diagnosis of COVID-19. Studies did not report FVC (\% of predicted) or DLCO (\% of predicted) or FVC $<80 \%$ of predicted or DLCO $<80 \%$ of predicted. Animal experiments,
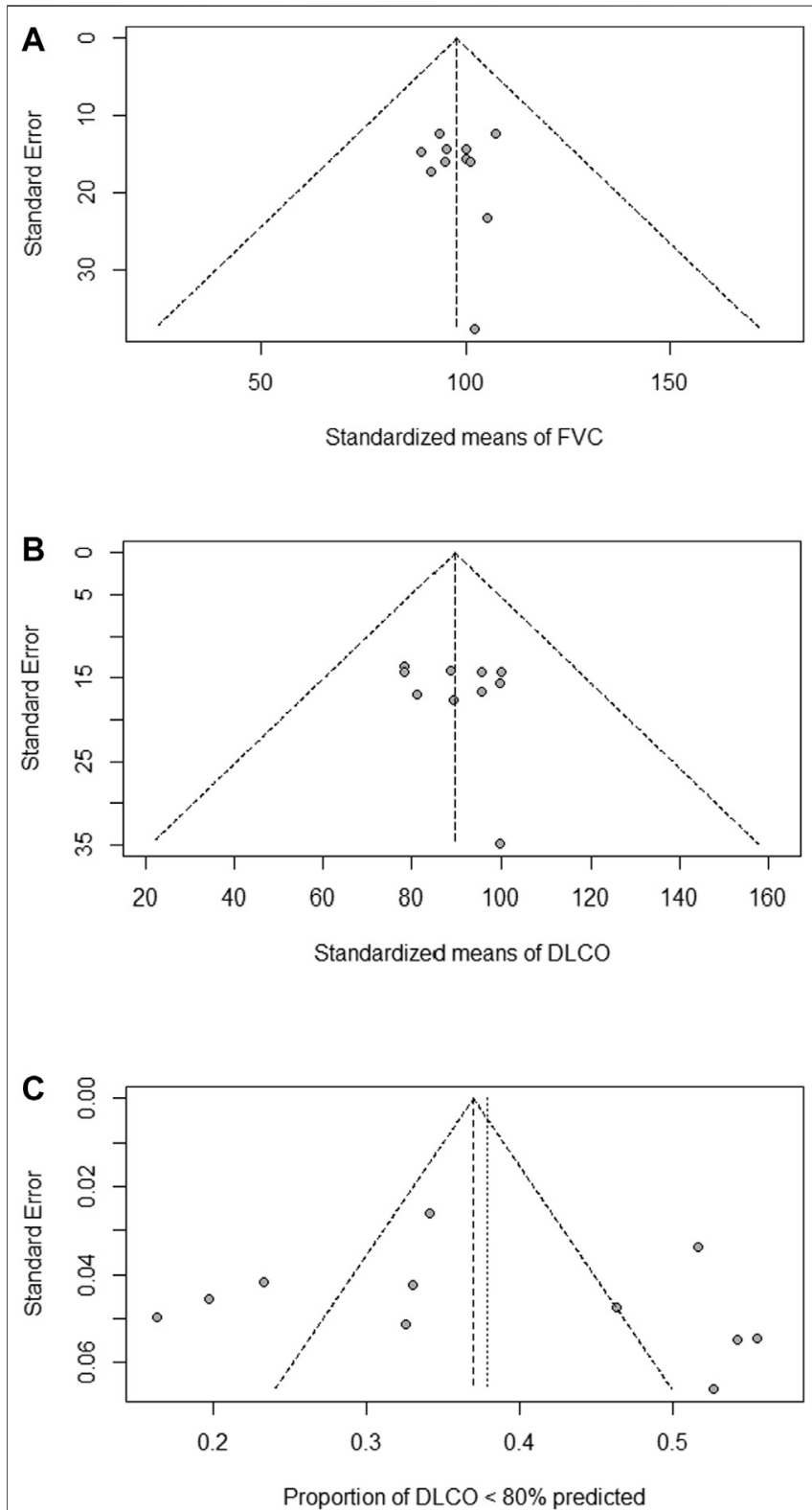

FIGURE 2 | No publication bias of the meta-analysis. Funnel plots of FVC (\% of predicted) (A), DLCO (\% of predicted) (B) and DLCO $<80 \%$ of predicted (C) were shown. Each dot represents a study. 
TABLE 1 | Basic characteristics of included studies.

\begin{tabular}{|c|c|c|c|c|c|c|c|c|c|}
\hline Author & Country & Design & $\begin{array}{l}\text { Participants } \\
\text { male/female }\end{array}$ & $\begin{array}{c}\text { Age } \\
\text { (years) }\end{array}$ & $\begin{array}{c}\text { BMI } \\
\text { (kg/m2) }\end{array}$ & Smoking & $\begin{array}{l}\text { Respiratory } \\
\text { comorbidities }\end{array}$ & $\begin{array}{c}\text { Time of } \\
\text { assessment }\end{array}$ & $\begin{array}{l}\text { Quality } \\
\text { rating }\end{array}$ \\
\hline $\begin{array}{l}\text { Huang } \\
\text { et al., } \\
(2020)\end{array}$ & China & retrospective & 57 26M/31F & $\begin{array}{l}46.7 \pm \\
13.7\end{array}$ & $23.9 \pm 3.5$ & $\begin{array}{l}\text { History of smoking } \\
9 \text { (15.7\%) }\end{array}$ & $\begin{array}{l}\text { No patient was } \\
\text { reported having } \\
\text { chronic repiratory } \\
\text { diseases }\end{array}$ & $\begin{array}{l}30 \text { days after } \\
\text { discharge from the } \\
\text { hospital }\end{array}$ & high \\
\hline $\begin{array}{l}\text { Venturelli } \\
\text { et al., } \\
\text { (2021) }\end{array}$ & Italy & prospective & $\begin{array}{l}767515 \mathrm{M} / \\
252 \mathrm{~F}\end{array}$ & $\begin{array}{l}63 \pm \\
13.6\end{array}$ & $\mathrm{NR}$ & $\begin{array}{l}\text { Active smoker } \\
33(4.3 \%) \\
\text { History of smoking } \\
179(23.3 \%)\end{array}$ & $\mathrm{NR}$ & $\begin{array}{l}81 \text { (66-106) days } \\
\text { after hospital } \\
\text { discharge }\end{array}$ & high \\
\hline $\begin{array}{l}\text { You et al., } \\
(2020)\end{array}$ & China & prospective & $1810 \mathrm{M} / 8 \mathrm{~F}$ & $\begin{array}{l}50.7 \pm \\
12.1\end{array}$ & $26.4 \pm 2.8$ & $\mathrm{NR}$ & $\begin{array}{l}\text { No patient was } \\
\text { reported having } \\
\text { chronic repiratory } \\
\text { diseases }\end{array}$ & $\begin{array}{l}38 \pm 13.4 \text { days } \\
\text { after hospital } \\
\text { discharge }\end{array}$ & high \\
\hline $\begin{array}{l}\text { Lerum } \\
\text { et al., } \\
\text { (2021) }\end{array}$ & Norway & prospective & $10354 \mathrm{M} / 49 \mathrm{~F}$ & $\begin{array}{l}59 \\
(49-72)\end{array}$ & $\begin{array}{l}25.8 \\
(23.8-29.6)\end{array}$ & $\begin{array}{l}\text { Current smoker } \\
3(3.4 \%) \\
\text { previous smoker } \\
34(39 \%)\end{array}$ & $\mathrm{NR}$ & $\begin{array}{l}3 \text { months after } \\
\text { hospital admission }\end{array}$ & poor \\
\hline $\begin{array}{l}\text { Daher } \\
\text { et al., } \\
(2020)\end{array}$ & Germany & prospective & 33 22M/11F & $64 \pm 3$ & $28(24-31)$ & $\mathrm{NR}$ & 7 (21\%) & $\begin{array}{l}6 \text { weeks after } \\
\text { hospital discharge }\end{array}$ & high \\
\hline $\begin{array}{l}\text { Wu et al., } \\
\text { (2021) }\end{array}$ & China & $\begin{array}{l}\text { prospective, } \\
\text { longitudinal, } \\
\text { cohort }\end{array}$ & $8347 \mathrm{M} / 36 \mathrm{~F}$ & $\begin{array}{l}60 \\
(52-66)\end{array}$ & $\begin{array}{l}25 \\
(23.5-27.1)\end{array}$ & NR & $\begin{array}{l}\text { No patient was } \\
\text { reported having } \\
\text { chronic repiratory } \\
\text { diseases }\end{array}$ & $\begin{array}{l}3 \text { months, } \\
6 \text { months, } \\
9 \text { months, } \\
12 \text { months after } \\
\text { hospital discharge }\end{array}$ & high \\
\hline $\begin{array}{l}\text { Liang et al., } \\
\text { (2020) }\end{array}$ & China & Prospective & $7621 \mathrm{M} / 55 \mathrm{~F}$ & $\begin{array}{l}41.3 \pm \\
13.8\end{array}$ & $23.7 \pm 4.5$ & NR & $\begin{array}{l}\text { Cough } 45 \text { (60\%) } \\
\text { Increased sputum } \\
\text { production } \\
33(43 \%) \\
\text { Activity chest } \\
\text { tightness and } \\
\text { palpitations } 47(62 \%)\end{array}$ & $\begin{array}{l}3 \text {-months follow- } \\
\text { up study after } \\
\text { discharge }\end{array}$ & high \\
\hline $\begin{array}{l}\text { Bellan } \\
\text { et al., } \\
\text { (2021) }\end{array}$ & Italy & $\begin{array}{l}\text { prospective } \\
\text { cohort study }\end{array}$ & 238 142M/96F & $\begin{array}{l}61 \\
(51-71)\end{array}$ & $\mathrm{NR}$ & $\begin{array}{l}\text { Never 139(58.4\%) } \\
\text { Former } 74(31.1 \%) \\
\text { Current 25(10.5\%) } \\
\text { Pack-years, } \\
\text { median(IQR) } \\
15(7.25-36)\end{array}$ & $\begin{array}{l}\text { No patient was } \\
\text { reported having } \\
\text { chronic repiratory } \\
\text { diseases }\end{array}$ & $\begin{array}{l}4 \text { months after } \\
\text { discharge }\end{array}$ & high \\
\hline $\begin{array}{l}\text { Li et al., } \\
(2020)\end{array}$ & China & $\begin{array}{l}\text { a prospective } \\
\text { study }\end{array}$ & 18 & NR & NR & $\begin{array}{l}\text { History of smoking } \\
3(16.6 \%)\end{array}$ & $\begin{array}{l}\text { history of } \\
\text { tuberculosis } 1 \text { (5.5\%) }\end{array}$ & $\begin{array}{l}\text { Near discharge and } \\
\text { in quarantine period } \\
\text { ( } 2 \text { weeks after } \\
\text { discharge) }\end{array}$ & high \\
\hline $\begin{array}{l}\text { van den } \\
\text { Borst et al., } \\
(2020)\end{array}$ & Netherlands & Prospective & $12474 \mathrm{M} / 50 \mathrm{~F}$ & $59 \pm 14$ & $\mathrm{NR}$ & $\begin{array}{l}\text { Never } 48(39 \%) \\
\text { Former } 74(60 \%) \\
\text { Current } 2(2 \%)\end{array}$ & $\begin{array}{l}\text { asthma } 12(10 \%) \\
\text { chronic lung } \\
\text { diseases } 23(19 \%) \\
\text { other lung diseases } \\
4(3 \%)\end{array}$ & $\begin{array}{l}\text { Three months after } \\
\text { recovery }\end{array}$ & high \\
\hline $\begin{array}{l}\text { Mo et al., } \\
(2020)\end{array}$ & China & Prospective & 110 55M/55F & $\begin{array}{l}49.1 \pm \\
14.0\end{array}$ & $23.5 \pm 3.0$ & $\begin{array}{l}\text { History of smoking } \\
13(11.8 \%)\end{array}$ & $\begin{array}{l}\text { asthma } 1(0.9 \%) \\
\text { chronic bronchitis } \\
1(0.9 \%) \\
\text { bronchiectasis } \\
1(0.9 \%)\end{array}$ & $\begin{array}{l}\text { At time of hospital } \\
\text { discharge }\end{array}$ & poor \\
\hline $\begin{array}{l}\text { Zhao et al., } \\
(2020)\end{array}$ & China & retrospective & 55 22M/23F & $\begin{array}{l}47.7 \pm \\
15.5\end{array}$ & NR & $\begin{array}{l}\text { active } 2(3.6 \%) \\
\text { former } 2(3.6 \%)\end{array}$ & cough 7 (43.75\%) & $\begin{array}{l}3 \text { months after } \\
\text { hospital discharge }\end{array}$ & high \\
\hline $\begin{array}{l}\text { Huang } \\
\text { et al., } \\
(2021)\end{array}$ & China & $\begin{array}{l}\text { prospective } \\
\text { cohort study }\end{array}$ & $\begin{array}{l}1733897 \mathrm{M} / \\
836 \mathrm{~F}\end{array}$ & $\begin{array}{l}57 \\
(47-65)\end{array}$ & NR & $\begin{array}{l}\text { Never-smoker } \\
1585 / 1731(92 \%) \\
\text { Current smoker } \\
102 / 1731(6 \%) \\
\text { Former smoker } \\
44 / 1731(3 \%)\end{array}$ & $\begin{array}{l}\text { Chronic obstructive } \\
\text { pulmonary disorder } \\
31(2 \%)\end{array}$ & $\begin{array}{l}153.0 \\
(146.0-160.0) \text { days } \\
\text { after hospital } \\
\text { discharge }\end{array}$ & high \\
\hline
\end{tabular}

$N R$, not reported; BMI, body mass index; $M$, male; $F$, female. 
TABLE 2 | Summary of studies included pulmonary function test.

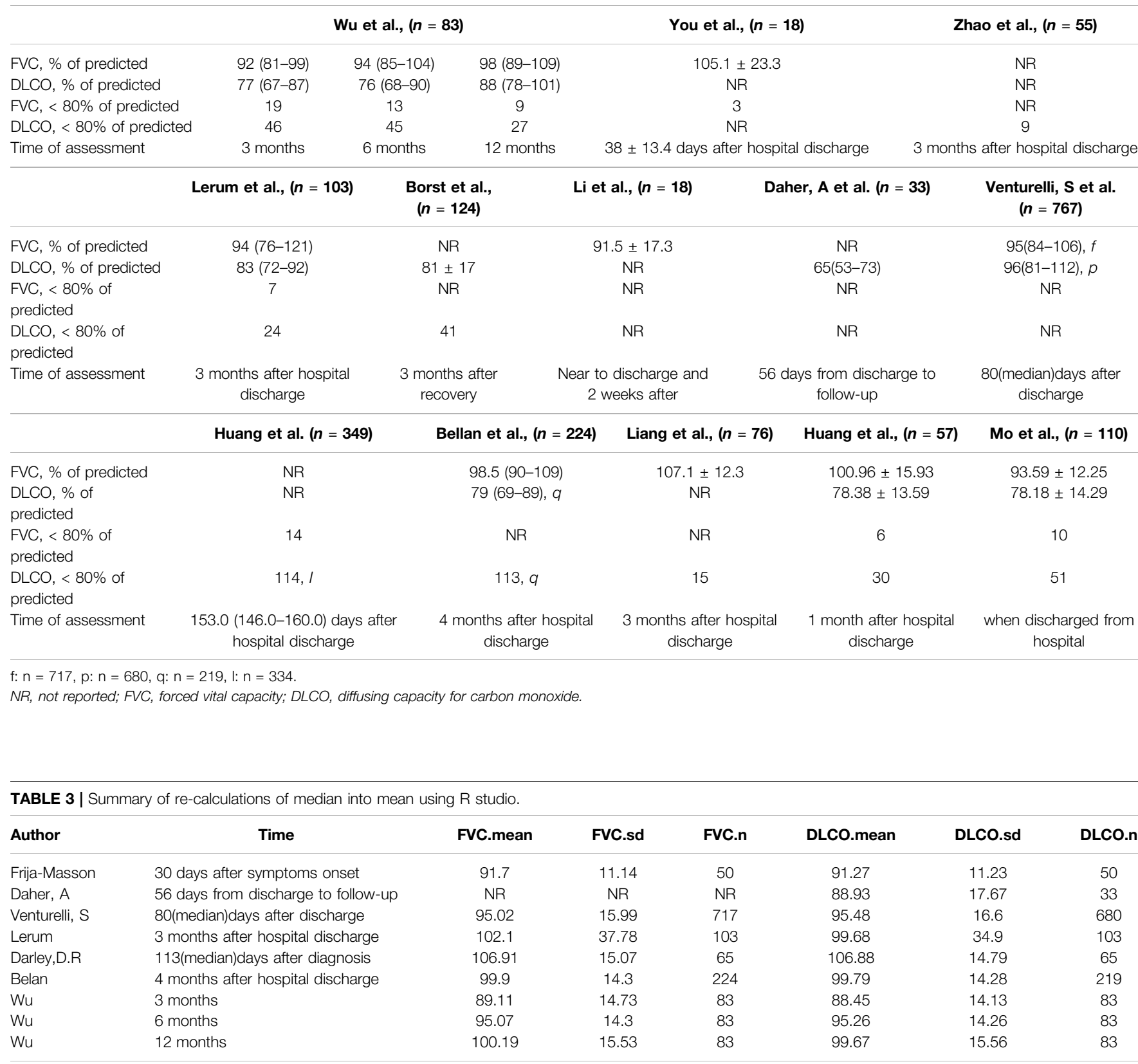

FVC, forced vital capacity; DLCO, diffusing capacity for carbon monoxide; NR, Not reported.

medical records, case reports, famous medical experience and review were excluded.

\section{Literature Retrieval and Selection}

Firstly, according to the literature inclusion criteria, two researchers independently searched at Pubmed, ScienceDirect, Embase and Web of Science. Secondly, two researchers selected the literature and extracted the data independently in accordance with the standard data extraction table. When it came to divergences, a third researcher did the judgement. After the discussion, researchers reached a consensus. Finally, after the extraction and input of the data, two independent researchers did the subsequent analysis.

\section{Extraction of Data}

According to the inclusion criteria, we assessed the design of research, patients, and outcome indicators. First author, published year, number of cases, nationality, ages, body mass index (BMI), smoking status, respiratory comorbidities, time of assessment and, index quantity of FVC, $\%$ of predicted, DLCO, $\%$ of predicted; FVC $<80 \%$ of 


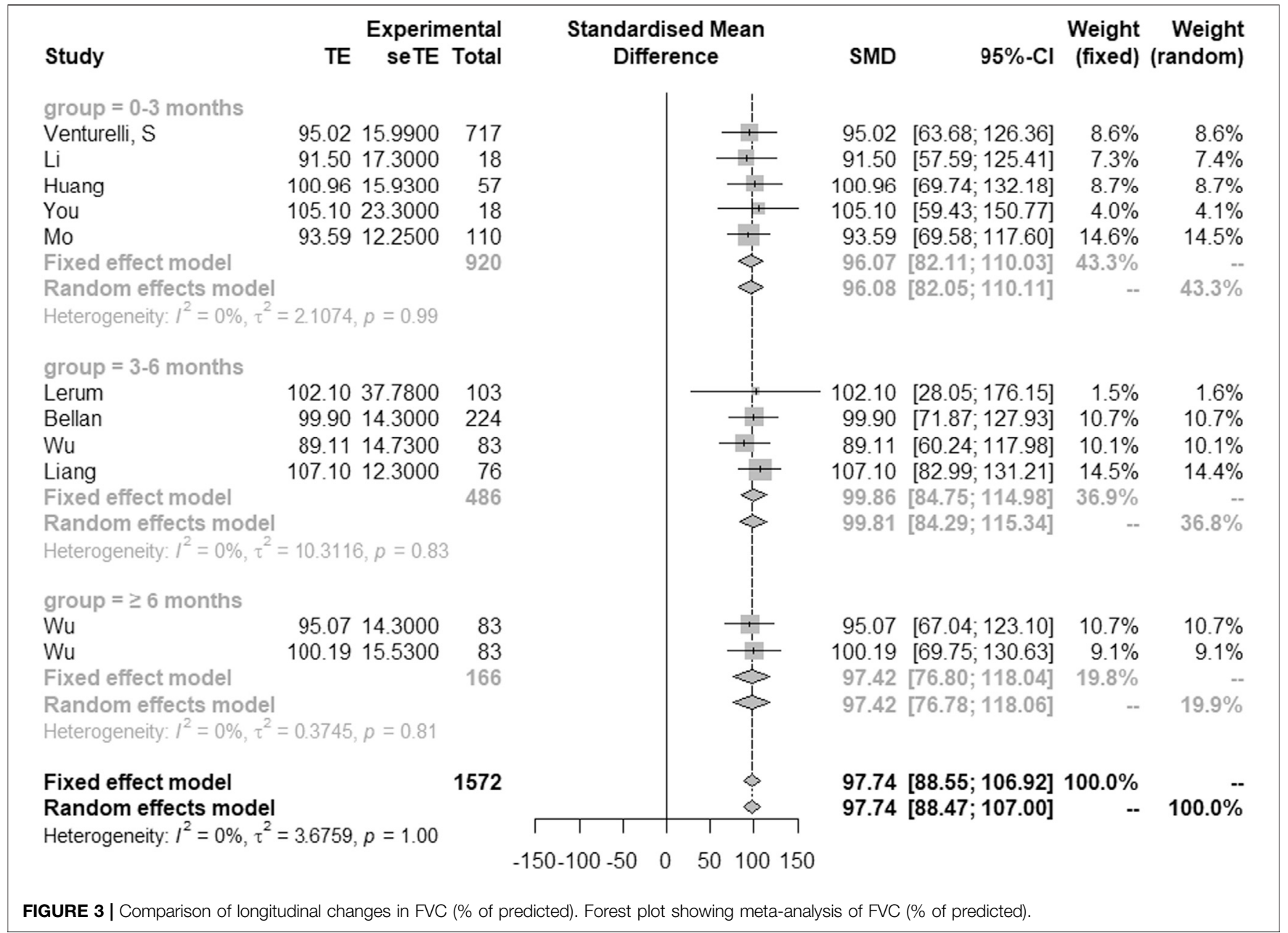

predicted and DLCO $<80 \%$ of predicted were extracted from eligible studies.

\section{Quality Assessment of Articles}

The studies with randomised controlled trials were evaluated by Newcastle-Ottawa Scale (Bellan et al., 2021). As for no controlled trials, it includes the following aspects: 1) selection: Representativeness of the exposed cohort, selection of the non-exposed cohort, Ascertainment of exposure, Demonstration that outcome of interest was not present at start of study; 2) comparability: Research control matched important factors, but also controlled other important factors; and 3) outcome: assessment of outcome, follow-up long enough for outcomes to occur, adequacy of follow up of cohorts.

\section{Synthesis and Analysis of Data}

We used package "meta (version 4.18-0)" in R 4.0.1 and R studio to perform meta-analysis of the following pulmonary function tests (PFTs) indexes (1. FVC, \% of predicted; 2. DLCO, $\%$ of predicted; 3 . FVC $<80 \%$ of predicted; 4 . DLCO $<80 \%$ of predicted.). Patients were divided into three groups: less than 3 months (0-3 months), more than or equal to
3 months and less than 6 months (3-6 months), and more than or equal to 6 months ( $\geq 6$ months). We re-calculated the median (first quantile, third quantile) to mean \pm standard deviation (SD) for FVC (\% of predicted) and DLCO (\% of predicted) in several studies. Statistical heterogeneity was measured through the $\mathrm{I}^{2}$ statistic and classified as low $\left(\mathrm{I}^{2}<25 \%\right)$, moderate $\left(\mathrm{I}^{2} 25-50 \%\right)$, and high $\left(\mathrm{I}^{2}>50 \%\right.$ ) (Melsen et al., 2014). Subgroup analysis, according to the outcome assessment and severity, was performed. Sensitivity analysis was also employed to assess the change in pooled prevalence due to the selective exclusion of studies.

\section{RESULTS}

\section{Literature Extraction}

A total of 1,123 articles was retrieved from databases via the retrieval methods. Duplicate literatures were excluded through titles and abstracts. By reading the full text, we excluded 1,110 papers and conference abstracts with incomplete or no specific research method. Finally, 13 papers published in English were included (Liang et al., 


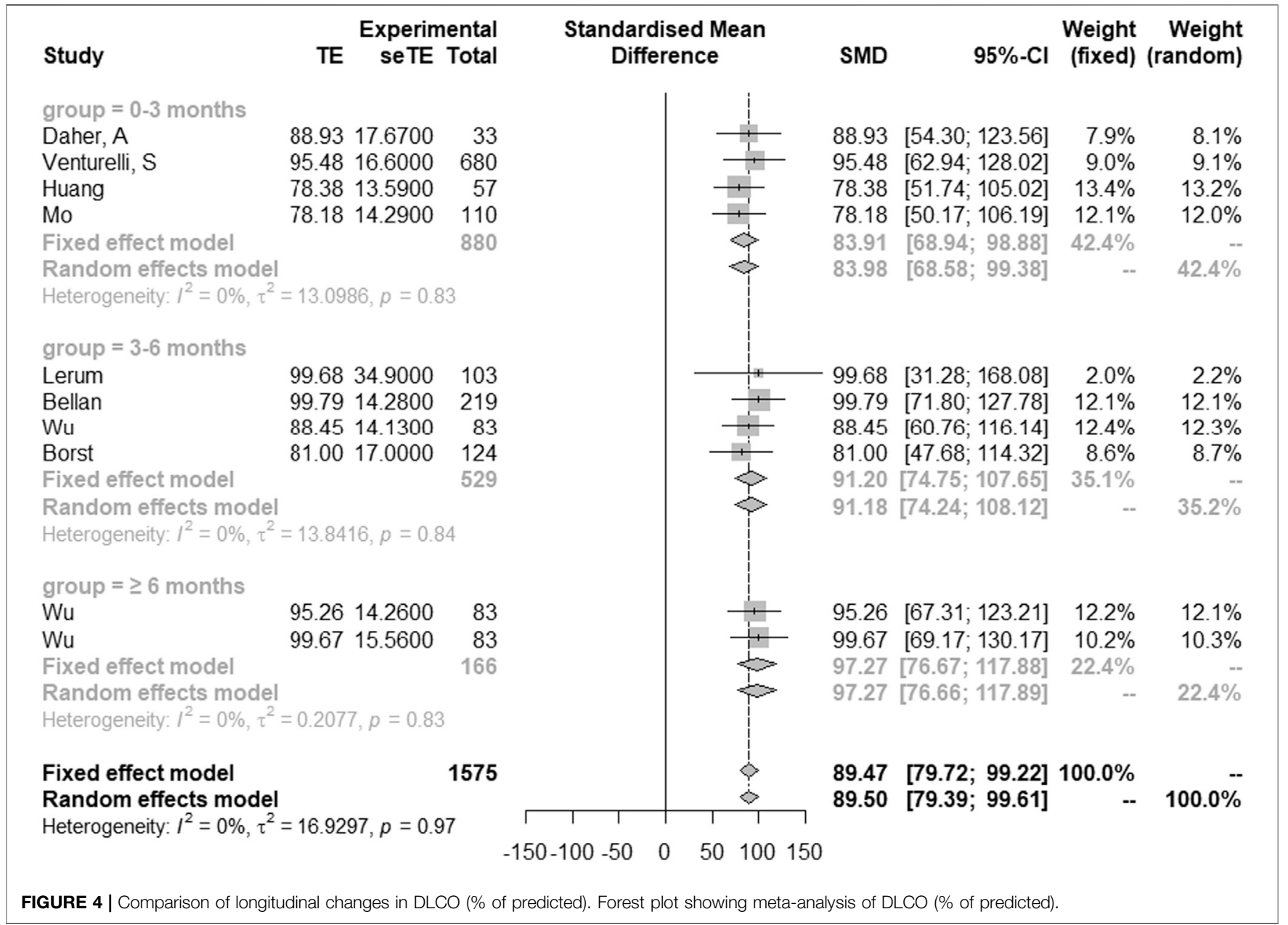

2020; Huang et al., 2020; Venturelli et al., 2021; You et al., 2020; Lerum et al., 2021; Daher et al., 2020; Wu et al., 2021; Bellan et al., 2021; Li et al., 2020; van den Borst et al., 2020; Mo et al., 2020; Zhao et al., 2020; Huang et al., 2021), with a total of 3,455 patients. The evaluation of the quality of included studies by Newcastle-Ottawa Scale (NOS) (Stang et al., 2018) showed that two studies had a poor quality and the rest 11 studies passed the quality control. The basic characteristics of the included literatures were detailed in Table 1 and the procedure of literature retrieval and selection was shown in Figure 1.

Among the included studies, 10 studies reported FVC (\% of predicted), eight studies reported DLCO (\% of predicted), six reported FVC $<80 \%$ of predicted, and nine reported DLCO $<80 \%$ of predicted. Wu et al. (2021). reported all the indexes of the patients after the 3, 6 and 12 months following COVID-19-related hospitalisation (Table 2). For those data reported in the form of median (first quantile, third quantile), we used $\mathrm{R}$ studio to re-calculate them into mean \pm SD (Table 3 ).

Publication bias refers to the fact that research results with statistical significance are more likely to be reported and published than those without statistical significance and invalid results (DeVito and Goldacre, 2019). We examined the publication bias of meta-analysis of each indicator. There was no publication bias in FVC (\% of predicted; $p=0.93$; Figure 2A), DLCO (\% of predicted; $p=0.54$; Figure 2B) and DLCO $(<80 \%$ of predicted; $p=0.94$; Figure $2 \mathrm{C})$. For FVC $<80 \%$ of predicted, less than 10 studies were included, so publication bias was not tested.

\section{Comparison of Longitudinal Changes in FVC (\% of Predicted)}

Nine studies with 11 groups of data showed the results of FVC (\% of predicted). Based on the time of patients discharged from hospital, we divided them into three groups: $0-3$ months, $3-6$ months and $\geq 6$ months. FVC (\% of predicted) in 0-3 months, 3-6 months and $\geq 6$ months post discharge were 96.1 (95\% CI [82.1-110.0]), 99.9 (95\% CI [84.8-115.0]) and 97.4 (95\% CI [76.8-118.0]), respectively. In this study, heterogeneity was extremely low $\left(\mathrm{I}^{2}=0 \%\right)$, and the overall value of FVC (\% of predicted) in all studies was 97.7 (95\% CI [88.6-106.9]) (Figure 3). 


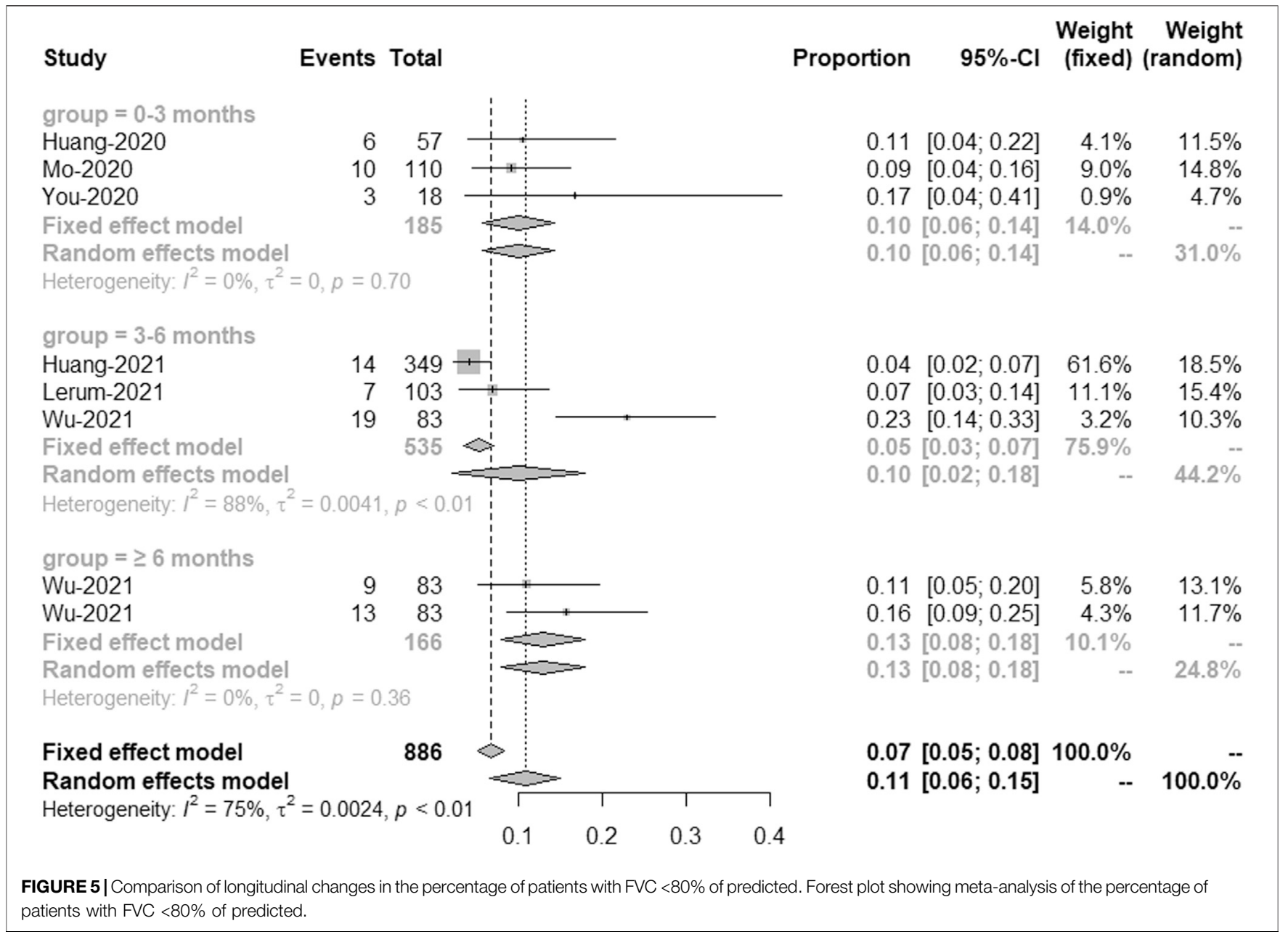

\section{Comparison of Longitudinal Changes in DLCO (\% of Predicted)}

Eight studies with 10 groups of data showed the results of DLCO (\% of predicted). DLCO (\% of predicted) in 0-3 months, 3-6 months and $\geq 6$ months post discharge were 83.9 (95\% CI [68.9-98.9]), 91.2 (95\% CI [74.8-107.7]) and 97.3 (95\% CI [76.7-117.9]), respectively. Heterogeneity was considered low $\left(\mathrm{I}^{2}=0 \%\right)$ using a fixed effect model (Melsen et al., 2014; Bellou et al., 2016) (Figure 4).

Comparison of longitudinal changes in the percentage of patients with FVC $<80 \%$ of predicted.

These included six studies, which in total have eight groups of data showed the percentage of patients with FVC less than $80 \%$ of predicted. Based on the time of patients being discharged from hospital, we divided them into three groups: 0-3 months, 3-6 months and greater than 6 months. Meta-analysis showed that the percentage of patients with FVC less than $80 \%$ of predicted in $0-3$ months, 3-6 months and $\geq 6$ months post discharge was $10 \%$ (95\% CI [6-14\%]), $10 \%$ (95\% CI [2-18\%]) and $13 \%$ (95\% CI [8-18\%], respectively. The heterogeneity of 3-6 months was large, so the sensitivity analysis was carried out in this study. We removed the study from $\mathrm{Wu}$ et al. and got the meta-analysis result of this subgroup, which was $4 \%\left(95 \%\right.$ CI [3-6\%]) with $\mathrm{I}^{2}=6 \%$ (Figure 5).

Comparison of longitudinal changes in the percentage of patients with DLCO $<80 \%$ of predicted.

This included nine studies, which have 11 groups of data shows the results of DLCO less than $80 \%$ of predicted. Metaanalysis showed a significant and persistent reduction in DLCO over the study period. The percentage of patients with DLCO less than $80 \%$ of predicted in 0-3 months, 3-6 months and $\geq 6$ months post discharge was $48 \%$ (95\% CI [41-56\%]), 33\% (95\% CI $[23-44 \%])$ and $43 \%(95 \%$ CI $[22-65 \%])$, respectively (Figure 6).

\section{DISCUSSION}

Post-acute COVID-19 syndrome, also known as long COVID, encompasses a wide range of physical and mental health symptoms that persist after recovery from acute SARS-CoV2 infections (Nalbandian et al., 2021). Systematic studies of sequelae after recovery from acute COVID-19 are demanded 


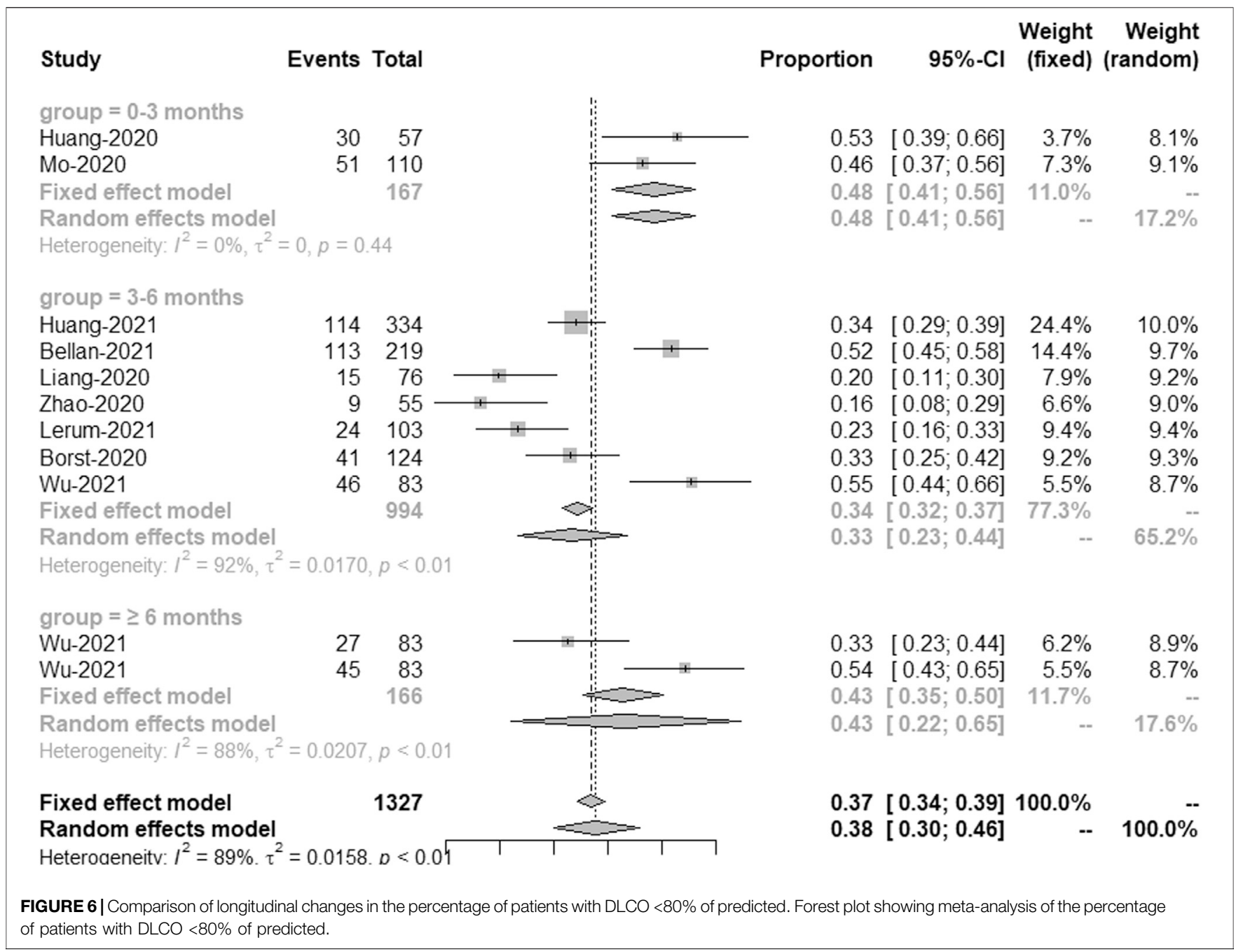

to inform effective clinical management for patients suffered from long COVID.

We recently reported the 3 months, 6 months, 9 months, and 12 months respiratory outcomes in patients following COVID-19-related hospitalisation from a relatively small prospective cohort $(n=83)$ (Wu et al., 2021). In this study, we conducted meta-analysis to determine the short (0-3 months), medium (3-6 months) and long (>6 months) respiratory outcomes in patients following COVID-19-related hospitalisation. Significantly, we found a persistent reduction in DLCO over the study period, consistent with earlier reports ( $E$ et al., 2021). Low DLCO could be caused by interstitial changes or pulmonary vascular abnormalities following COVID-19 infections (Lang et al., 2020; Patel et al., 2020; Hanidziar and Robson, 2021). Our study has shown that up to a third of COVID patients still have evidence of defect DLCO 1 year after discharge ( $\mathrm{Wu}$ et al., 2021), although longer term follow-up with a larger cohort will be required to confirm this observation.
In general, the heterogeneity of the studies included in the meta-analysis was low. However, the heterogeneity of DLCO less than $80 \%$ of predicted was higher, which may be caused by different ethnic groups, ages, disease severity, therapies and other factors. In general, the models we used were robust and reliable.

There are several limitations in this study. Firstly, age, sex ratio, nationality and disease severity of the patients included in the study are quite different, which may cause great heterogeneity and affect the final research results. Secondly, we only selected four indicators of lung function, so we cannot investigate the relationship between other indicators and discharge time. To be consistent and comparable with our earlier publication ( $\mathrm{Wu}$ et al., 2021), we excluded those studies without data on FVC and/or DLCO values $<80 \%$ of predicted. This might cause some false positive results considering the mean age of included patients is over 50 (van den Borst et al., 2020; Barisione and Brusasco, 2021; Milanese et al., 2021). In addition, pre-existing comorbidities for most COVID-19 patients are not known, which might cause certain 
bias of the results. Despite of these limitations, our findings in this meta-analysis are consistent with our previous report (Wu et al., 2021), confirming a high prevalence of persistent lung diffusion impairment in patients following COVID-19-related hospitalisation. Routine respiratory follow-up is thus strongly recommended.

\section{DATA AVAILABILITY STATEMENT}

The original contributions presented in the study are included in the article/Supplementary Material, further inquiries can be directed to the corresponding author.

\section{REFERENCES}

Barisione, G., and Brusasco, V. (2021). Lung diffusing capacity for nitric oxide and carbon monoxide following mild-to-severe COVID-19. Physiol. Rep. 9 (4), e14748. doi:10.14814/phy2.14748

Bellan, M., Soddu, D., Balbo, P. E., Baricich, A., Zeppegno, P., Avanzi, G. C., et al. (2021). Respiratory and Psychophysical Sequelae Among Patients With COVID-19 Four Months after Hospital Discharge. JAMA Netw. Open 4 (1), e2036142. doi:10.1001/jamanetworkopen.2020.36142

Bellou, V., Belbasis, L., Tzoulaki, I., Evangelou, E., and Ioannidis, J. P. A. (2016). Environmental risk factors and Parkinson's disease: An umbrella review of meta-analyses. Parkinsonism Relat. Disord. 23, 1-9. doi:10.1016/ j.parkreldis.2015.12.008

Daher, A., Balfanz, P., Cornelissen, C., Müller, A., Bergs, I., Marx, N., et al. (2020). Follow up of patients with severe coronavirus disease 2019 (COVID-19): Pulmonary and extrapulmonary disease sequelae. Respir. Med. 174, 106197. doi:10.1016/j.rmed.2020.106197

DeVito, N. J., and Goldacre, B. (2019). Catalogue of bias: publication bias. Bmj Ebm 24 (2), 53-54. doi:10.1136/bmjebm-2018-111107

Dhawan, R. T., Gopalan, D., Howard, L., Vicente, A., Park, M., Manalan, K., et al. (2021). Beyond the clot: perfusion imaging of the pulmonary vasculature after COVID-19. Lancet Respir. Med. 9 (1), 107-116. doi:10.1016/s2213-2600(20) 30407-0

Ekbom, E., Frithiof, R., Emilsson, Öi., Larson, I.M., Lipcsey, M., Rubertsson, S., et al. (2021). Impaired diffusing capacity for carbon monoxide is common in critically ill Covid-19 patients at four months post-discharge. Respir. Med. 182, 106394. doi:10.1016/j.rmed.2021.106394

Hanidziar, D., and Robson, S. C. (2021). Hyperoxia and modulation of pulmonary vascular and immune responses in COVID-19. Am. J. Physiology-Lung Cell Mol. Physiol. 320 (1), L12-L16. doi:10.1152/ ajplung.00304.2020

Huang, C., Huang, L., Wang, Y., Li, X., Ren, L., Gu, X., et al. (2021). 6month consequences of COVID-19 in patients discharged from hospital: a cohort study. The Lancet 397 (10270), 220-232. doi:10.1016/s01406736(20)32656-8

Huang, Y., Tan, C., Wu, J., Chen, M., Wang, Z., Luo, L., et al. (2020). Impact of coronavirus disease 2019 on pulmonary function in early convalescence phase. Respir. Res. 21 (1), 163. doi:10.1186/s12931-020-01429-6

Hull, J. H., Lloyd, J. K., and Cooper, B. G. (2020). Lung function testing in the COVID-19 endemic. Lancet Respir. Med. 8 (7), 666-667. doi:10.1016/s2213$2600(20) 30246-0$

Lang, M., Som, A., Mendoza, D. P., Flores, E. J., Reid, N., Carey, D., et al. (2020). Hypoxaemia related to COVID-19: vascular and perfusion abnormalities on dual-energy CT. Lancet Infect. Dis. 20 (12), 1365-1366. doi:10.1016/s14733099(20)30367-4

Lerum, T. V., Aaløkken, T. M., Brønstad, E., Aarli, B., Ikdahl, E., Lund, K. M. A., et al. (2021). Dyspnoea, lung function and CT findings 3 months after hospital admission for COVID-19. Eur. Respir. J. 57 (4), 2003448. doi:10.1183/ 13993003.03448-2020

\section{AUTHOR CONTRIBUTIONS}

YW conceived and designed the study. TG, FJ, YL, YZ and YL collected the data. TG and FJ performed the data analysis. TG and YL did the evaluation of the quality of included articles. TG and YW wrote the article. All authors are responsible for reviewing data. All authors read and approved the final article.

\section{FUNDING}

YW was supported by Medical Research Council (United Kingdom) (MR/S025480/1).

Li, X., Wang, C., Kou, S., Luo, P., Zhao, M., and Yu, K. (2020). Lung ventilation function characteristics of survivors from severe COVID19: a prospective study. Crit. Care 24 (1), 300. doi:10.1186/s13054-02002992-6

Liang, L., Yang, B., Jiang, N., Fu, W., He, X., Zhou, Y., et al. (2020). Three-month Follow-up Study of Survivors of Coronavirus Disease 2019 after Discharge. J. Korean Med. Sci. 35 (47), e418. doi:10.3346/ jkms.2020.35.e418

Melsen, W. G., Bootsma, M. C. J., Rovers, M. M., and Bonten, M. J. M. (2014). The effects of clinical and statistical heterogeneity on the predictive values of results from meta-analyses. Clin. Microbiol. Infect. 20 (2), 123-129. doi:10.1111/14690691.12494

Milanese, M., Anselmo, M., Buscaglia, S., Garra, L., Goretti, R., Parodi, L., et al. (2021). COVID-19 6 months after hospital discharge: pulmonary function impairment and its heterogeneity. ERJ Open Res. 7 (3), 00196-02021. doi:10.1183/23120541.00196-2021

Mo, X., Jian, W., Su, Z., Chen, M., Peng, H., Peng, P., et al. (2020). Abnormal pulmonary function in COVID-19 patients at time of hospital discharge. Eur. Respir. J. 55 (6), 2001217. doi:10.1183/ 13993003.01217-2020

Nalbandian, A., Sehgal, K., Gupta, A., Madhavan, M. V., McGroder, C., Stevens, J. S., et al. (2021). Post-acute COVID-19 syndrome. Nat. Med. 27 (4), 601-615. doi:10.1038/s41591-021-01283-z

Patel, B. V., Arachchillage, D. J., Ridge, C. A., Bianchi, P., Doyle, J. F., Garfield, B., et al. (2020). Pulmonary Angiopathy in Severe COVID-19: Physiologic, Imaging, and Hematologic Observations. Am. J. Respir. Crit. Care Med. 202 (5), 690-699. doi:10.1164/rccm.202004-1412oc

Stang, A., Jonas, S., and Poole, C. (2018). Case study in major quotation errors: a critical commentary on the Newcastle-Ottawa scale. Eur. J. Epidemiol. 33 (11), 1025-1031. doi:10.1007/s10654-018-0443-3

Thomas, M., Price, O. J., and Hull, J. H. (2021). Pulmonary function and COVID-19. Curr. Opin. Physiol. 21, 29-35. doi:10.1016/ j.cophys.2021.03.005

van den Borst, B., Peters, J. B., and Brink, M. (2020). Comprehensive health assessment three months after recovery from acute COVID-19. Clin. Infect. Dis. doi:10.1093/cid/ciaa1750

Venturelli, S., Benatti, S. V., Casati, M., Binda, F., Zuglian, G., Imeri, G., et al. (2021). Surviving COVID-19 in Bergamo province: a post-acute outpatient re-evaluation. Epidemiol. Infect. 149, e32. doi:10.1017/ s0950268821000145

Worldometers (2020). World Meter Corona Virus Update. (Live) Available from https://www.worldometers.info/coronavirus/.

Wu, X., Liu, X., Zhou, Y., Yu, H., Li, R., Zhan, Q., et al. (2021). 3-month, 6-month, 9-month, and 12-month respiratory outcomes in patients following COVID19-related hospitalisation: a prospective study. Lancet Respir. Med. 9 (7), 747-754. doi:10.1016/S2213-2600(21)00174-0

You, J., Zhang, L., Ni-Jia-Ti, M.-y. -d. -l., Zhang, J., Hu, F., Chen, L., et al. (2020). Anormal pulmonary function and residual CT abnormalities in rehabilitating COVID-19 patients after discharge. J. Infect. 81 (2), e150-e152. doi:10.1016/ j.jinf.2020.06.003 
Zhao, Y.-m., Shang, Y.-m., Song, W.-b., Li, Q.-q., Xie, H., Xu, Q.-f., et al. (2020). Follow-up study of the pulmonary function and related physiological characteristics of COVID-19 survivors three months after recovery. EClinicalMedicine 25, 100463. doi:10.1016/j.eclinm.2020.100463

Conflict of Interest: The authors declare that the research was conducted in the absence of any commercial or financial relationships that could be construed as a potential conflict of interest.

Publisher's Note: All claims expressed in this article are solely those of the authors and do not necessarily represent those of their affiliated organizations, or those of the publisher, the editors, and the reviewers. Any product that may be evaluated in this article, or claim that may be made by its manufacturer, is not guaranteed or endorsed by the publisher.

Copyright (C) 2021 Guo, Jiang, Liu, Zhao, Li and Wang. This is an open-access article distributed under the terms of the Creative Commons Attribution License (CC BY). The use, distribution or reproduction in other forums is permitted, provided the original author(s) and the copyright owner(s) are credited and that the original publication in this journal is cited, in accordance with accepted academic practice. No use, distribution or reproduction is permitted which does not comply with these terms. 